\title{
Kandungan Fenol dan Aktivitas Antioksidan Makroalga Bentik Caulerpa racemosa (Forsskal) dari Teluk Hurun, Lampung
}

\author{
Phenol Content and Antioxidant Activity of Benthic Macroalga Caulerpa racemosa \\ (Forsskal) from Hurun Bay, Lampung
}

\author{
Joko Santoso $^{1 *}$, Diini Fitriani ${ }^{2}$, dan Yusli Wardiatno ${ }^{3}$ \\ ${ }^{1}$ Departemen Teknologi Hasil Perairan, Fakultas Perikanan dan Ilmu Kelautan, IPB, Bogor 16680 \\ ${ }^{2}$ Balai Besar Riset Pengolahan Produk dan Bioteknologi Kelautan dan Perikanan \\ Badan Riset Kelautan dan Perikanan, Kementerian Kelautan dan Perikanan, Jakarta 10260 \\ ${ }^{3}$ Departemen Manajemen Sumberdaya Perairan, Fakultas Perikanan dan Ilmu Kelautan, IPB, Bogor 16680 \\ E-mail: joko2209@yahoo.com*Penulis untuk korespondensi
}

\begin{abstract}
Caulerpa racemosa is a green benthic macroalga that mainly grows in tropical regions which is expected to bask of strong ultraviolet radiation from sunlight. This circumstance can cause to increase levels of reactive radical species. To reduce and/or protect, organism like macroalga may change its metabolism and stimulate to produce some active compounds, therefore, tropical macroalgae are estimated possessing a large number of active compounds such as antioxidant. In this experiment, edible green benthic macroalga Caulerpa racemosa grown in different water condition were used. The content of total phenol and antioxidant activity of ethyl acetate extract were performed. Pearson correlation between waters condition and antioxidant activities i.e. total phenol and DPPH inhibition were also analyzed. Caulerpa racemosa grown in station 2, exposed in strong radiation from sunlight, had the highest content of total phenol and percentage of DPPH inhibition, with their values were $12.60 \%$ and $46.43 \%$ respectively. Sunlight intencity in waters had strong positive correlation to the total phenol content and reducing activity of DPPH, however, parameters of nitrate and ammonia had strong negative correlation.
\end{abstract}

Key words: Antioxidant, Caulerpa racemosa, DPPH, macroalga, phenol

\begin{abstract}
Abstrak
Caulerpa racemosa adalah makroalga hijau bentik, terutama tumbuh di daerah tropis yang mendapat paparan kuat radiasi ultraviolet dari sinar matahari. Kondisi tersebut dapat menyebabkan meningkatnya jumlah senyawa reaktif radikal. Untuk mengurangi dan/atau melindungi diri, organisme seperti makroalga mengubah metabolismenya dan menstimulasi pembentukan beberapa senyawa aktif, sehingga makroalga tropis diduga mempunyai kandungan senyawa aktif seperti antioksidan. Dalam penelitian ini, makroalga hijau bentik Caulerpa racemosa yang tumbuh di kondisi perairan berbeda digunakan. Kandungan total fenol dan aktivitas antioksidan ekstrak etil asetat diuji. Korelasi Pearson antara kondisi perairan dan aktivitas antioksidan yaitu total fenol dan penghambatan DPPH juga dianalisis. Caulerpa racemosa yang tumbuh di stasiun 2, mendapat paparan radiasi kuat dari sinar matahari, mempunyai kandungan total fenol dan persen penghambatan DPPH tertinggi, dengan nilai berturut-turut $12,60 \%$ dan $46,43 \%$. Intensitas sinar matahari perairan mempunyai korelasi positif kuat terhadap kandungan total fenol dan penurunan aktivitas DPPH, sedangkan parameter nitrat dan amonia mempunyai korelasi negatif kuat.
\end{abstract}

Kata kunci: Antioksidan, Caulerpa racemosa, DPPH, makroalga, fenol

Diterima: 08 Maret 2010, disetujui: 01 September 2010

\section{Pendahuluan}

Antioksidan secara umum didefinisikan sebagai senyawa yang dapat menunda atau mencegah oksidasi lemak atau molekul lain dengan menghambat proses inisiasi atau propagasi reaksi rantai oksidatif (Rohman et al., 2006; Nielseon dan Jacobsen, 2009). 
Berdasarkan sumbernya, antioksidan dikelompokkan menjadi dua yaitu antioksidan endogen yang diproduksi tubuh dan antioksidan eksogen yang harus dipasok dari luar melalui asupan makanan (Wresdiyati et al., 2004 dan 2005). Antioksidan yang dihasilkan tubuh berupa enzim seperti katalase, hidrogen peroksidase dan superoksida dismutase (Food dan Nutrition Board, 2000; Kumalaningsih, 2006; Je et al., 2009); sedangkan antioksidan yang diperoleh dari asupan makanan dapat digolongkan menjadi antioksidan zat gizi (vitamin A, C, E, mineral Se) dan antioksidan non-gizi (senyawa fenol) (Papas, 1999; Kaur dan Kapoor, 2001; Marin et al., 2004). Selain itu ada juga antioksidan sintetik yang sering digunakan dalam bahan pangan. Dua jenis antioksidan sintetik yang umum digunakan adalah butylated hydroxyanisol (BHA) dan butylated hydroxytoluene (BHT) (Winarno, 1997; Farag et al., 1989).

Penggunaan BHA dan BHT saat ini berangsur-angsur digantikan oleh antioksidan alami yang dinilai lebih aman, sehingga penelitian dalam pencarian sumber-sumber antioksidan alami banyak dilakukan. Sampai saat ini ada satu pemahaman bahwa antioksidan alami adalah senyawa fenolik yang terdapat pada seluruh bagian tanaman meliputi senyawa flavonoid, asam sinamat, kumarin, tokoferol, karotenoid, dan asam polifungsional organik (Shahidi dan Wanasundara, 1992).

Salah satu sumber antioksidan alami yang berpotensi untuk dikaji lebih dalam adalah rumput laut yang termasuk ke dalam kelompok makroalga bentik. Penelitian membuktikan bahwa rumput laut memproduksi senyawa antioksidan seperti pada jenis Sargassum polycystum, Sargassum marginatum, Padina tetrastimatica, Turbinaria conoides (Santoso et al., 2004; Chandini et al., 2008); Ulva lactuca, Ulva reticulata (Santoso et al., 2004; Abd ElBaky et al., 2009); Porphyra sp (Yoshiki et al., 2009; Lopez-Lopez et al., 2009); Kappaphycus alvarezii (Kumar et al., 2008); Undaria pinnatifida (Je et al., 2009); Caulerpa sertularoides, Caulerpa racemosa, Caulerpa lentilifera (Santoso et al., 2004; Santoso et al., 2009; Santoso et al., 2010). Senyawa antioksidan pada rumput laut termasuk golongan metabolit sekunder yaitu berbagai senyawa kimiawi yang tidak secara nyata mempunyai fungsi primer dalam pertumbuhan sel tanaman, tetapi disintesis sebagai respons terhadap rangsangan dari luar dan seringkali memerankan fungsi pengaturan pada reaksi fisiologis dan metabolisme terhadap stres, serangan hama atau pengganggu (Brandt dan Molgaard, 2001; Benbrook, 2005).

Pada penelitian ini digunakan rumput laut Caulerpa racemosa dari kelompok alga hijau yang dimanfaatkan oleh sebagian penduduk lokal daerah pesisir di Indonesia sebagai sayuran (Kadi, 1996; Kadi, 2000). Belum adanya informasi tentang pengaruh lingkungan perairan terhadap kandungan dan aktivitas senyawa antioksidan Caulerpa racemosa khususnya yang tumbuh di perairan Indonesia, melatarbelakangi perlunya dilakukan penelitian. Penelitian bertujuan meneliti pengaruh kondisi lingkungan perairan terhadap kandungan senyawa fenol rumput laut Caulerpa racemosa dan menganalisis aktivitas antioksidan.

\section{Metode Penelitian}

\section{Waktu dan Tempat}

Penelitian dibagi menjadi dua tahap yaitu penelitian lapangan dan laboratorium. Penelitian dilakukan pada tanggal 28 April-12 Mei 2009 bertempat di Teluk Hurun, Lampung (Gambar 1) dengan tiga stasiun pengambilan sampel yaitu stasiun 1 (posisi $105^{\circ} 14^{\prime}$ 988' LS dan $05^{\circ} 31^{\prime}$ 360 “ BT), stasiun 2 (posisi $105^{\circ} 15^{\prime} 657^{\prime}$ ” LS dan $05^{\circ} 31^{\prime}$ 090" BT), dan stasiun 3 (posisi $105^{\circ}$ 16'98" LS dan 05' 31'384" BT). Penetapan stasiun pengambilan sampel didasarkan pada perbedaan kondisi perairan seperti kedalaman, jarak dari bibir pantai, substrat tempat tumbuh, dan paparan sinar matahari yang diduga memengaruhi pembentukan senyawa antioksidan (Benbrook, 2005; Moore et al., 2006).

Selama periode penelitian lapangan, dilakukan pengamatan kondisi lingkungan perairan ketiga stasiun secara in situ yaitu pengukuran suhu, salinitas, kecerahan, kecepatan arus, oksigen terlarut, intensitas cahaya, dan kedalaman. Selain itu juga dilakukan analisis kualitas air di laboratorium meliputi $\mathrm{pH}$, nitrat, fosfat dan amonia. 
Penelitian laboratorium diawali dengan pengamatan secara visual kondisi rumput laut di ketiga stasiun. Dilanjutkan dengan pengambilan sampel, pencucian, pengeringan dengan sinar matahari dan ekstraksi rumput laut serta evaluasi karakteristik antioksidan.

\section{Bahan dan Alat}

Jenis pelarut yang digunakan dalam ekstraksi senyawa antioksidan Caulerpa racemosa yang berasal dari ketiga stasiun penelitian adalah etil asetat. Bahan-bahan kimia untuk analisis kualitas air (kandungan nitrat, fosfat dan amonia) adalah sodium arsenat, brucine, asam sulfat, ammonium molibdat, fenol, dan sodium nitroposida. Bahan-bahan kimia untuk analisis kandungan total fenol meliputi natrium hidroksida, bromat bromida, asam klorida pekat, kalium iodida dan amilum. Bahanbahan kimia untuk uji aktivitas antioksidan dengan metode DPPH adalah 1,1-diphenyl-2picrylhydrazyl (DPPH), asam askorbat sebagai kontrol positif, buffer asetat dan metanol proanalysis sebagai pelarut. Bahan-bahan kimia tersebut diperoleh dari Merck Darmstadt Germany; Sigma Chemical Corp. St Louis, MO USA; dan Wako Pure Chemical Industries Ltd. Osaka Japan.

Peralatan yang digunakan dalam penelitian meliputi refraktometer, stopwacth, DO-meter, termometer, lux-meter, neraca analitik, blender, cawan mortar, cawan porselen, sonikator, sentrifuse, magnetic stirrer, hot plate, kertas saring kasar, kertas saring Whatman no. 42, botol ekstrak sampel $15 \mathrm{ml}$ dan $60 \mathrm{ml}$, botol vial $75 \mathrm{ml}$, peralatan gelas, inkubator, vaccum rotary evaporator, waterbath, micropippette dan spektrofotometer $U V$-Visible (UV-Vis) Hitachi U-2800.

\section{Pengamatan Rumput Laut Segar}

Pengamatan rumput laut segar dilakukan secara visual dengan melihat kesegaran, warna thallus dan bentuk buah, serta rangkaian thallus. Selain itu juga diukur panjang thallus (frond) dan pengamatan habitat tempat tumbuhnya rumput laut (Kadi, 1996; Kadi, 2000).

\section{Preparasi Rumput Laut Kering}

Preparasi rumput laut kering diawali dengan pembersihan dan pencucian rumput laut segar menggunakan air laut untuk menghilangkan berbagai macam benda asing seperti batu-batuan, lumpur, dan rumput laut jenis lainnya. Selanjutnya diperkecil ukurannya dan dikeringkan di bawah sinar matahari hingga kering. Rumput laut kering, dihaluskan dengan blender dan disimpan dalam wadah gelas tertutup (Santoso et al., 2009; Santoso et al., 2010).

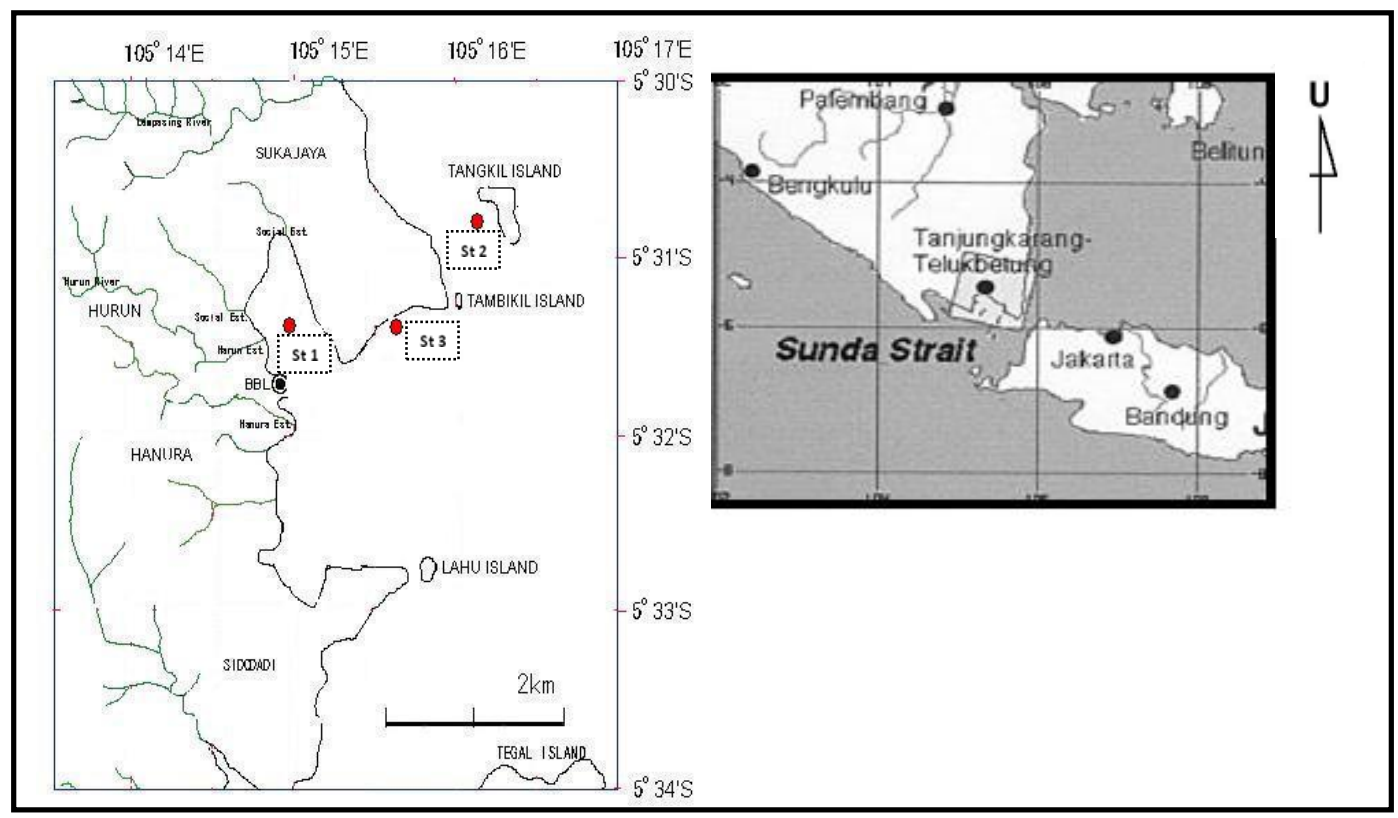

Gambar 1. Lokasi stasiun pengambilan sampel di Teluk Hurun Lampung. 


\section{Ekstraksi Rumput Laut}

Ekstraksi yang dilakukan adalah ekstraksi tunggal, menggunakan pelarut etil asetat. Prosedur ekstraksi mengacu pada metode Santoso et al., (2004) dengan modifikasi. Sampel kering ditimbang sebanyak $2 \mathrm{~g}$, ditambahkan pelarut etil asetat sebanyak $20 \mathrm{ml}$ dan dilakukan sonikasi selama 5 menit. Dilakukan penambahan pelarut sebanyak $25 \mathrm{ml}$, dimaserasi selama 24 jam pada suhu ruang dengan magnetic stirer dan tahap terakhir adalah sonikasi kedua selama 5 menit. Selanjutnya, dilakukan sentrifugasi selama 10 menit pada $6000 \mathrm{rpm}$ dan $4^{\circ} \mathrm{C}$, difiltrasi menggunakan kertas saring Whatman nomor 42. Filtrat yang dihasilkan dievaporasi dengan vaccum rotary evaporator pada suhu $40^{\circ} \mathrm{C}$ sampai ekstrak menjadi pasta. Ekstrak kasar yang diperoleh dilakukan analisis kandungan total fenol dan uji aktivitas antioksidan menggunakan metode 1,1diphenyl-2-picrylhydrazyl (DPPH).

\section{Analisis Parameter Fisika dan Kimia Perairan}

Pengukuran suhu dan salinitas masingmasing dilakukan dengan TM 6801B digital termometer dan portabel refraktometer FG 211. Pengukuran kecerahan dilakukan dengan sechidish. Kecepatan arus diukur dengan menggunakan alat pengukur arus dari kayu yang berbentuk silang dan stopwacth. Pengukuran oksigen terlarut dilakukan dengan Ion Catch SLC DO-meter. Pengukuran intensitas cahaya dengan LUX/FC Light-meter DL-204. Pengukuran $\mathrm{pH}$ dilakukan dengan mengacu metode elektrometri (APHA, 1998), nitrat dengan metode brucine (APHA, 1998), fosfat dan amonia dengan metode spektrofotometri (Byod, 1979; APHA 1998).

\section{Analisis Kandungan Total Fenol}

Kandungan total fenol diukur secara kolorimetri (AOAC, 1995) yaitu mereaksikan sampel dengan natrium hidroksida, bromat bromida, asam klorida pekat, kalium iodida dan amilum sebagai indikator. Selanjutnya, dilakukan titrasi menggunakan sodium tiosulfat sampai sampel berubah warna menjadi bening. Total fenol dihitung dengan rumus:$$
\text { (a }-\mathrm{b}) \times \mathrm{N} \text { tiosulfat } \mathrm{x}(\mathrm{BM} \text { fenol/6) } \mathrm{x} 1000
$$$$
\text { Total Fenol }(\%)=\frac{0,1 \times \text { berat sampel }(\mathrm{g})}{0} \times 100 \%
$$

Keterangan :

$\mathrm{a}=$ volume titrasi larutan tiosulfat dalam sampel $(\mathrm{ml})$ $\mathrm{b}=$ volume titrasi larutan tiosulfat dalam blanko $(\mathrm{ml})$

$6=$ jumlah atom brom yang digunakan dalam proses bromisasi

\section{Uji Aktivitas Antioksidan dengan Metode DPPH}

Aktivitas antioksidan diukur berdasarkan kemampuan penghambatan radikal bebas 1,1diphenyl-2-picrylhydrazyl (DPPH), Molyneux (2004) dengan modifikasi. Sebanyak $45 \mu \mathrm{L}$ ekstrak rumput laut dicampur dengan $1,50 \mathrm{~mL}$ buffer asetat $0,10 \mathrm{M}$ pH 7; ditambah dengan $2,905 \mathrm{ml}$ metanol dan $150 \mu \mathrm{L}$ DPPH yang memiliki konsentrasi $1 \mathrm{mg} / \mathrm{mL}$. Larutan dikocok dan diinkubasi pada suhu $37^{\circ} \mathrm{C}$ selama 20 menit dalam kondisi gelap. Asam askorbat (1-16 $\mathrm{mg} / \mathrm{mL}$ ) digunakan sebagai kontrol positif. Absorbansi yang dihasilkan diukur menggunakan spektrofotometer $U V$-Visible pada panjang gelombang $517 \mathrm{~nm}$. Aktivitas penangkapan terhadap radikal bebas ditetapkan sebagai persentase penghambatan dihitung berdasarkan persamaan:

Penghambatan $(\%)=\frac{\mathrm{AB}-\mathrm{AS}}{\mathrm{AB}} \times 100 \%$

Keterangan:

$\mathrm{AB}=$ absorbansi blanko

$\mathrm{AS}=$ absorbansi larutan substrat atau sampel

\section{Analisis Data}

Data dianalisis dengan analisis ragam, faktor tunggal yaitu lokasi pengambilan sampel (stasiun) dengan menggunakan uji lanjut Duncan. Hasil analisis parameter fisika kimia air yang menunjukkan beda nyata antarstasiun dikorelasikan dengan dua parameter yaitu total fenol dan aktivitas antioksidan, menggunakan uji korelasi Pearson (Steel dan Torrie, 1980). Analisis ragam dan uji Duncan dilakukan dengan menggunakan software SPSS 13, sedangkan analisis korelasi Pearson dilakukan dengan Microsoft Office Excel 2007.

\section{Hasil dan Pembahasan}

\section{Parameter Fisika Kimia Perairan}

Hasil pengukuran kualitas fisika dan kimia perairan selama periode 28 April-12 Mei 2009 di ketiga stasiun penelitian tertera pada Tabel 1. 
Parameter kecepatan arus, cahaya, nitrat, amonia dan oksigen terlarut dipengaruhi oleh lokasi pengamatan; sedangkan parameter suhu, salinitas, $\mathrm{pH}$ dan fosfat tidak dipengaruhi oleh lokasi pengamatan.

Komposisi dan distribusi dari jenis alga laut berhubungan dengan kemampuan dari tiaptiap jenis dalam mentoleransi kondisi lingkungan juga berhubungan dengan variasi pasang surut (Huckle et al., 2000). Nilai rata-rata kecepatan arus pada stasiun 3 lebih tinggi dibandingkan dengan stasiun lainnya terkait dengan lokasi stasiun 3 yang sejajar dengan pantai. Pada saat pasang, arus di lokasi diindikasikan sebagai arus momentum yang dipantulkan sejajar garis pantai di sekitar daerah breaker line (dekat stasiun 3), yang kemudian dibelokkan oleh arus massa air teluk dalam, yang hendak keluar teluk melalui ambang utara (Muchtar, 2005).

Rumput laut merupakan organisme yang memperoleh makanan melalui aliran air yang melewatinya. Gerakan air atau arus yang cukup akan menghindari terkumpulnya kotoran pada thallus, membantu pengudaraan (oksigen terlarut), dan mencegah adanya fluktuasi yang besar terhadap salinitas dan suhu air (Puja et al., 2001).

Nilai kecepatan arus yang tinggi pada stasiun 2 juga menyebabkan nilai oksigen terlarut lebih tinggi dibandingkan dengan stasiun 1 dan 3. Kisaran rata-rata nilai oksigen terlarut 5,07-6,00 $\mathrm{mg} / \mathrm{mL}$ mengindikasikan bahwa lokasi mengalami pencemaran ringan, terkait dengan adanya aktivitas mariculture yaitu budidaya ikan, kerang mutiara dan tambak udang. Lee et al., (1978) mengelompokkan nilai oksigen terlarut antara 4,50-6,50 mg/L ke dalam perairan tercemar ringan, dan bila lebih dari 6,50 $\mathrm{mg} / \mathrm{L}$ tergolong perairan yang tidak tercemar yang berarti masih alami.

Intensitas cahaya rata-rata tertinggi didapat pada stasiun 2, diikuti stasiun 3 dan 1 . Tingginya intensitas cahaya matahari menurut Reyes dan Zevallos (2003) adalah salah satu pemicu stres yang dapat meningkatkan biosintesis kandungan senyawa fenol pada jaringan tanaman.

Kandungan nitrat, amonia, dan fosfat di stasiun 1 relatif lebih tinggi dibandingkan stasiun 2 dan 3. Tingginya nilai ini diduga terkait dengan adanya aktivitas mariculture di sekitar lokasi di antaranya tambak udang, budidaya kerang mutiara, budidaya kerapu dan ikan lainnya.

\section{Kondisi Fisik Caulerpa racemosa}

Benbrook (2005) menyatakan bahwa kesehatan tanaman merupakan salah satu faktor yang memengaruhi kandungan antioksidan tanaman, karena itu evaluasi terhadap kondisi fisik Caulerpa racemosa penting dilakukan. Perbandingan kondisi fisik Caulerpa racemosa (Tabel 2).

Hasil pengamatan menunjukkan bahwa pertumbuhan Caulerpa racemosa terbaik berturut-turut adalah pada stasiun 1, stasiun 2 dan stasiun 3. Hal berkaitan dengan tingginya kandungan nitrat, amonia dan fosfat di stasiun 1 sebagai akibat adanya aktivitas mariculture di sekitar lokasi. Davis et al., (1997) menyatakan bahwa tingkat nitrogen yang tersedia dalam jumlah tinggi, menyebabkan tanaman cenderung tumbuh cepat dan memiliki ukuran besar.

\section{Kandungan Total Fenol}

Senyawa fenol merupakan senyawa yang banyak terdapat pada tanaman dan jenisnya sangat banyak. Beberapa di antaranya sudah diketahui struktur kimianya. Sebagian besar senyawa fenol dapat diidentifikasi dengan menggunakan sinar UV. Semua senyawa fenol memiliki gugus aromatik yang menyerap kuat pada spektrum sinar UV (Harborne, 1984). Gambar 2 menunjukkan bahwa kandungan total fenol ekstrak etil asetat rumput laut kering Caulerpa racemosa dipengaruhi secara nyata oleh lokasi pengambilan sampel. Caulerpa racemosa yang tumbuh di stasiun 2 mempunyai kandungan total fenol tertinggi yaitu $12,60 \%$ dan berbeda nyata dengan yang tumbuh di stasiun 1 $(2,20 \%)$ dan $3(3,10 \%)$.

Akumulasi senyawa fenol pada jaringan tanaman dapat disebabkan oleh berbagai stress abiotik seperti intensitas cahaya (Reyes dan Zevallos, 2003). Beberapa senyawa fenol yang berhasil diidentifikasi dari rumput laut marga Caulerpa yang tumbuh di perairan Indonesia dan Jepang adalah kelompok katekin terdiri dari galo-katekin, epi-katekin dan katekin-galat (Santoso et al., 2002; Yoshie et al., 2000). 
Tabel 1. Nilai parameter fisika kimia perairan.

\begin{tabular}{lcccc}
\hline \multirow{2}{*}{ Parameter } & \multirow{2}{*}{ Satuan } & \multicolumn{3}{c}{ Lokasi Pengamatan } \\
\cline { 3 - 5 } & & Stasiun 1 & Stasiun 2 & Stasiun 3 \\
\hline \hline Suhu & ${ }^{\circ} \mathrm{C}$ & $31,05^{\mathrm{a}}$ & $30,98^{\mathrm{a}}$ & $31,15^{\mathrm{a}}$ \\
Salinitas & $\mathrm{PSU}$ & $32,25^{\mathrm{a}}$ & $32,25^{\mathrm{a}}$ & $31,50^{\mathrm{a}}$ \\
Arus & $\mathrm{m} / \mathrm{detik}$ & $0,10^{\mathrm{a}}$ & $0,15^{\mathrm{ab}}$ & $0,22^{\mathrm{b}}$ \\
Intensitas cahaya & $\mathrm{Lux}$ & $397^{\mathrm{a}}$ & $516^{\mathrm{c}}$ & $425^{\mathrm{b}}$ \\
$\mathrm{pH}$ & - & $8,11^{\mathrm{a}}$ & $8,12^{\mathrm{a}}$ & $8,10^{\mathrm{a}}$ \\
Nitrat & $\mathrm{mg} / \mathrm{l}$ & $0,28^{\mathrm{b}}$ & $0,03^{\mathrm{a}}$ & $0,29^{\mathrm{b}}$ \\
Amonia & $\mathrm{mg} / \mathrm{l}$ & $0,32^{\mathrm{b}}$ & $0,28^{\mathrm{a}}$ & $0,29^{\mathrm{a}}$ \\
Fosfat & $\mathrm{mg} / \mathrm{l}$ & $0,096^{\mathrm{a}}$ & $0,093^{\mathrm{a}}$ & $0,094^{\mathrm{a}}$ \\
Oksigen terlarut & $\mathrm{mg} / \mathrm{l}$ & $5,74^{\mathrm{b}}$ & $6,00^{\mathrm{b}}$ & $5,07^{\mathrm{a}}$ \\
\hline \hline
\end{tabular}

Keterangan: Angka-angka pada tabel merupakan nilai rata-rata pada kondisi pasang dan surut. Angka-angka pada baris yang sama dan diikuti dengan huruf superscripts berbeda (a, b, c) menunjukkan beda nyata $(p<$ $0,05)$.

Tabel 2. Kondisi fisik Caulerpa racemosa.

\begin{tabular}{|c|c|c|c|}
\hline \multirow{2}{*}{ Parameter } & \multicolumn{3}{|c|}{ Lokasi Pengamatan } \\
\hline & Stasiun 1 & Stasiun 2 & Stasiun 3 \\
\hline 1. Kesegaran thallus & segar & segar & layu \\
\hline 2. Warna buah & hijau terang & hijau terang & hijau tua \\
\hline 3. Bentuk buah & didominasi bentuk bel & didominasi bentuk bel & didominasi bentuk bel \\
\hline 4. Rangkaian thallus & $\begin{array}{l}\text { secara bebas ditutupi oleh } \\
\text { buah yang terangkai tidak } \\
\text { beraturan dengan jumlah } \\
\text { buah rata-rata }>10\end{array}$ & $\begin{array}{l}\text { secara bebas ditutupi oleh } \\
\text { buah yang terangkai tidak } \\
\text { beraturan dengan jumlah } \\
\text { buah rata-rata } \geq 10\end{array}$ & $\begin{array}{l}\text { secara bebas ditutupi oleh } \\
\text { buah yang terangkai tidak } \\
\text { beraturan dengan jumlah buah } \\
\text { rata-rata }<10\end{array}$ \\
\hline 5. Panjang thallus (frond) & $8 \mathrm{~cm}$ & $8 \mathrm{~cm}$ & $6 \mathrm{~cm}$ \\
\hline 6. Habitat & $\begin{array}{l}\text { tumbuh di tali dengan } \\
\text { kedalaman } 1-2 \mathrm{~m}\end{array}$ & $\begin{array}{l}\text { tumbuh di tali dengan } \\
\text { kedalaman } 1-2 \mathrm{~m}\end{array}$ & $\begin{array}{l}\text { tumbuh pada substrat liat- } \\
\text { pasir- rubble dan karang mati } \\
\text { dengan kedalaman } 5-10 \mathrm{~m}\end{array}$ \\
\hline
\end{tabular}

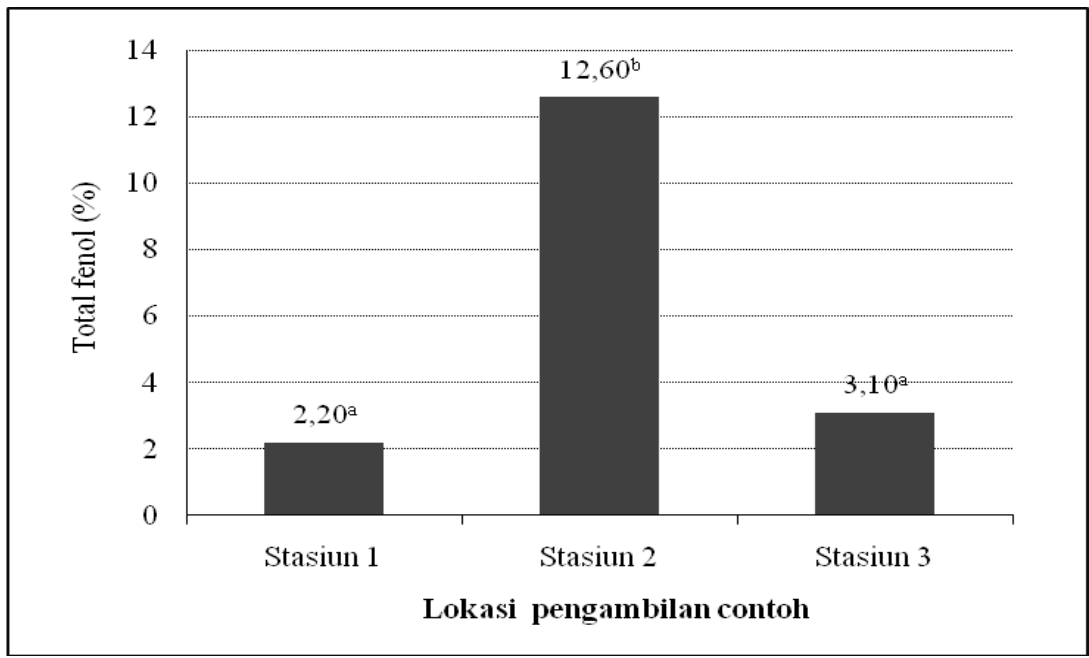

Gambar 2. Kandungan total fenol ekstrak rumput laut Caulerpa racemosa.

Keterangan: Angka-angka pada histogram yang diikuti huruf superscripts berbeda $(\mathrm{a}, \mathrm{b})$ menunjukkan berbeda nyata $(p<0,05)$. 
Berdasarkan uji korelasi antara parameter kualitas air dan total fenol, diketahui bahwa variabel amonia dan nitrat memiliki korelasi negatif; sedangkan cahaya, arus dan oksigen terlarut memiliki korelasi positif (Tabel 3). Cahaya memiliki korelasi yang sangat kuat dengan total fenol, tetapi parameter nitrat, amonia dan oksigen terlarut memiliki korelasi yang lemah dan arus memiliki korelasi sangat lemah. Ada hubungan yang jelas antara tingkat cekaman pada tumbuhan dan produksi metabolit sekunder, termasuk fenol dan senyawa antioksidan lain (Benbrook, 2005).

Tingginya kandungan total fenol di stasiun 2 berdasarkan hasil pengamatan terhadap parameter habitatnya didukung oleh 3 faktor yaitu: cahaya matahari, keberadaan herbivor, kondisi atau kesehatan tanaman. Menurut Reyes dan Zevallos (2003) cahaya matahari adalah salah satu bentuk pemicu stress yang dapat meningkatkan biosintesis kandungan senyawa fenol pada jaringan tanaman. Keberadaan herbivora sebagai salah satu faktor yang menyebabkan tingginya kandungan total fenol. Dixon dan Paiva (1995) melaporkan bahwa banyak senyawa fenilpropanoid terbentuk sebagai respons atas luka atau pemangsaan hewan herbivora. Selama periode pengamatan di stasiun 2 dijumpai binatang herbivora yaitu penyu antara 2-3 ekor. Luka akibat pemangsaan mendorong pembentukan asam klorogenik, alkil ferulat esters dan ikatan ester fenolik yang dapat berfungsi sebagai senyawa pertahanan (Dixon dan Paiva, 1995). Faktor lain yang diduga berkaitan dengan tingginya kandungan total fenol di stasiun 2 adalah kondisi fisik atau kesehatan tanaman. Hal ini disebabkan oleh tanaman yang sehat dapat melakukan metabolisme dengan baik termasuk melakukan biosintesis senyawa fenol (Riechert dan Dawes, 1986; Shahidi dan Wanasundara, 1992; Shiu dan Lee, 2005).

\section{Aktivitas Antioksidan Ekstrak Caulerpa racemosa Berdasarkan Penangkapan Radikal Bebas DPPH}

Radikal bebas merupakan molekul yang sangat reaktif dan tidak stabil karena mempunyai satu elektron atau lebih yang tidak berpasangan. Radikal bebas bereaksi dengan cara mengambil elektron molekul lain yang bersifat stabil, sehingga akan terbentuk radikal bebas baru. Reaksi ini akan terus berulang dan akan membentuk sebuah rantai yang mengakibatkan rusaknya membran sel dan komponen lainnya seperti protein dan DNA (Kaur dan Kapoor, 2001). Penghentian reaksi radikal bebas, diperlukan adanya antioksidan. Berdasarkan cara reaksinya Kaur dan Kapoor (2001); Moure et al., (2001); Wang et al., (2009) mendefinisikan antioksidan sebagai komponen yang dapat menghentikan reaksi radikal bebas pada proses oksidasi dengan cara memberikan elektron atau atom hidrogen pada senyawa yang mengandung radikal bebas.

Senyawa 1,1-diphenyl-2-picrylhydrazyl (DPPH) adalah radikal bebas yang bersifat stabil dan beraktivitas dengan cara mendelokalisasi elektron bebas pada suatu molekul, sehingga molekul tersebut tidak reaktif sebagaimana radikal bebas yang lain (Molyneux, 2004). Senyawa antioksidan akan bereaksi dengan radikal DPPH melalui donasi atom hidrogen (Chen et al., 2008; Sharma dan Bhat, 2009).

Gambar 3 terlihat bahwa ekstrak Caulerpa racemosa stasiun 2 mempunyai persentase penghambatan tertinggi $(46,43 \%)$ dan berbeda nyata dengan stasiun $3(36,97 \%)$ dan 1 $(20,76 \%)$. Terdapat korelasi positif antara kandungan total fenol dan aktivitas penghambatan radikal bebas DPPH. Hasil penelitian sejalan dengan yang telah dilakukan oleh Santoso et al., (2009) dan Santoso et al., (2010) menunjukkan bahwa kandungan total fenol ekstrak etil asetat Caulerpa racemosa dan Caulerpa lentilifera dalam kondisi segar dan kering berbanding lurus dengan aktivitas antioksidan.

Uji korelasi antara parameter kualitas air dan aktivitas antioksidan yang dinyatakan dalam persen penghambatan radikal bebas DPPH (Tabel 4). Paramater cahaya mempunyai korelasi positif sangat kuat (94\%) terhadap persen penghambatan radikal bebas DPPH, sedangkan parameter nitrat dan amonia mempunyai korelasi negatif kuat dengan nilai berturut-turut $82 \%$ dan $72 \%$. Parameter arus mempunyai korelasi lemah (48\%) dan oksigen terlarut korelasinya sangat lemah, dengan persen korelasi hanya $17 \%$.

Hipotesis yang dibuat oleh para ahli patologi, fisiologi dan entomologi tanaman dan dibuktikan dengan hasil penelitian; bahwa 
keberadaan, jumlah dan aktivitas senyawa antioksidan sebagai metabolit sekunder tanaman yang tinggi diproduksi sebagai respons terhadap stress biotik dan abiotik serta tingkat produksinya merupakan fungsi genetik, lingkungan pertumbuhan dan kesehataan tanaman (Benbrook, 2005). Hubungan antara cahaya matahari dan aktivitas antioksidan hasil penelitian sesuai dengan pernyataan Shiu dan Lee (2005) bahwa paparan sinar ultraviolet-B yang berasal dari matahari memicu terbentuknya radikal bebas. Keberadaan radikal bebas, dilawan oleh makhluk hidup termasuk makroalga dengan membangun sistem pertahanan antioksidan alami secara endogen dalam bentuk enzim. Hasil penelitian yang dilakukan Aguilerra et al., (2002) dalam Shiu dan Lee (2005) membuktikan bahwa stress oksidatif pada makroalga di Laut Artik berkorelasi positif dengan aktivitas enzim superoksida dismutase, hidrogen peroksidase, dan katalase yang termasuk dalam antioksidan endogen.

Adanya korelasi negatif kuat antara kandungan nitrat dan amonia dengan persen penghambatan radikal bebas DPPH terkait dengan dibutuhkannya nitrogen dalam fungsi primer tanaman, yaitu untuk pertumbuhan bukan untuk memproduksi metabolit sekunder. Davis et al., (2004) menyatakan bahwa tingkat nitrogen yang tersedia dalam jumlah tinggi, menyebabkan tanaman cenderung tumbuh cepat dan memiliki ukuran besar, tetapi konsentrasi polifenol dan beberapa vitamin rendah. Fenomena tersebut dikenal sebagai dilution effect.

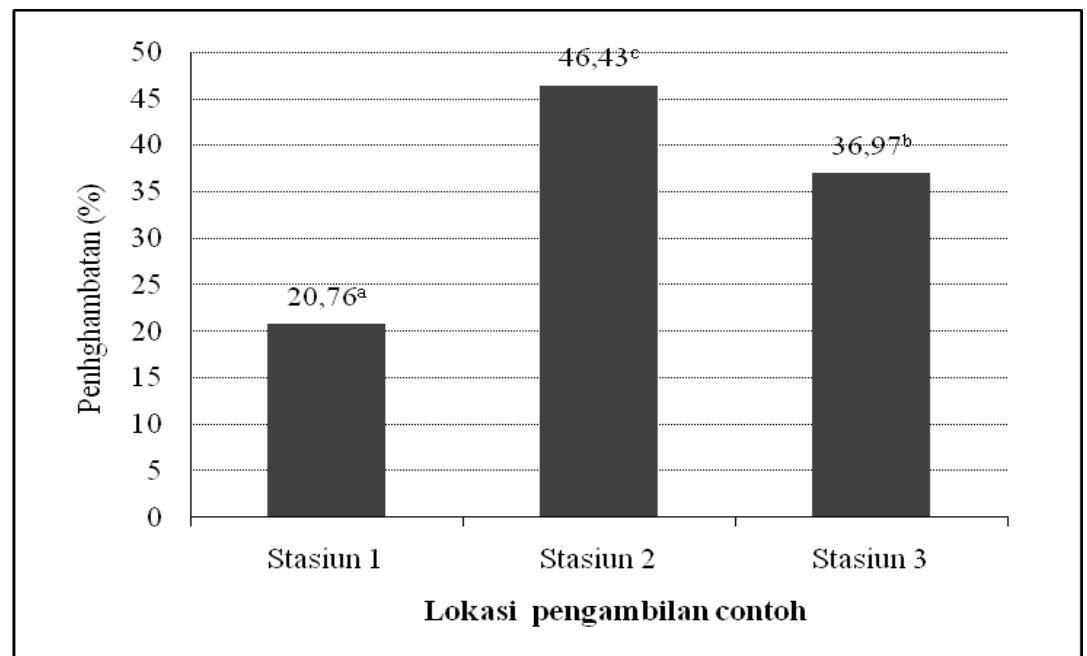

Gambar 3. Histogram penghambatan ekstrak rumput laut Caulerpa racemosa terhadap radikal bebas DPPH.

Keterangan: Angka-angka pada histogram yang diikuti huruf superscripts berbeda $(\mathrm{a}, \mathrm{b})$ menunjukkan berbeda nyata $(p<0,05)$.

Tabel 3. Hubungan antara parameter fisik kimia perairan dan total fenol.

\begin{tabular}{ll}
\hline \multicolumn{1}{c}{ Hubungan Antarparameter } & Korelasi Pearson $(\mathbf{r})$ \\
\hline \hline 1. Cahaya dengan total fenol & 0,98 \\
2. Kecepatan arus dengan total fenol & 0,01 \\
3. Amonia dengan total fenol & $-0,51$ \\
4. Nitrat dengan total fenol & $-0,42$ \\
5. Oksigen terlarut dengan total fenol & 0,51 \\
\hline \hline
\end{tabular}

Tabel 4. Hubungan antara parameter fisik kimia perairan dengan penghambatan radikal bebas DPPH.

\begin{tabular}{ll}
\hline \multicolumn{1}{c}{ Hubungan Antarparameter } & Korelasi Pearson (r) \\
\hline \hline 1. Cahaya dengan penghambatan radikal bebas DPPH & 0,94 \\
2. Kecepatan arus dengan penghambatan radikal bebas DPPH & 0,48 \\
3. Amonia dengan penghambatan radikal bebas DPPH & $-0,72$ \\
4. Nitrat dengan penghambatan radikal bebas DPPH & $-0,82$ \\
5. Oksigen terlarut dengan penghambatan radikal bebas DPPH & 0,17 \\
\hline \hline
\end{tabular}




\section{Simpulan dan Saran}

\section{Simpulan}

Kandungan total fenol Caulerpa racemosa dan aktivitas penghambatan radikal bebas DPPH dipengaruhi oleh kondisi lingkungan perairan tempat tumbuhnya. Faktor intensitas cahaya matahari berkorelasi positif kuat dengan kandungan total fenol dan penghambatan radikal bebas DPPH, sedangkan kandungan nitrat dan amonia berkorelasi negatif.

\section{Saran}

Perlu dilakukan penelitian lebih lanjut yaitu penapisan, pemurnian dan identifikasi senyawa fenol yang terdapat pada makroalga bentik Caulerpa racemosa, serta uji aktivitas antioksidan secara in vivo dengan menggunakan kultur jaringan sebagai model seperti Caco- 2 cell.

\section{Ucapan Terima Kasih}

Ucapan terima kasih disampaikan kepada Sdr. Windhika Priyatmoko atas bantuannya dalam pengambilan data in situ. Balai Besar Pengembangan Budidaya Laut Lampung atas fasilitas laboratorium dalam analisis kualitas air dan fasilitas penginapan selama penelitian lapangan.

\section{Daftar Pustaka}

Abd El-Baky, H.H., El-Baz, F.K. dan El-Baroty, G.S. 2009. Natural Preservative Ingredient from Marine Alga Ulva lactuca L. Int. J. Food Sci. Tech., 44: 1688-1695.

American Public Health Association, American Waterwork Association and Water Pollution Control Federation (APHA). 1998. Standard Methods for Examination of Water and Wastewater $20^{\text {th }}$ ed. American Public Health Association, Washington DC.

Analysis of the Association of Official Analytical Chemists (AOAC). 1995. Official Methods Of Analysis of the Association of Official Analytical Chemists. Association of Official Analytical Chemistry, Maryland.

Benbrook, C.M. 2005. Elevating Antioxidant Levels in Food through Organic Farming and Food Processing. Organic Center State of Science, New York.

Brandt, K. dan Molgaard, J.P. 2001. Organic Agriculture: Does It Enhance or Reduce the Nutritional Value of Plant Foods? J. Sci. Food Agric., 81: 924-931.
Byod, C.E. 1979. Water Quality in Warm Water Fish ponds. Auburn University Agricultural Experiment Station, Alabama.

Chandini, S.K., Ganesan, P. dan Bhaskar, N. 2008. In Vitro Antioxidant Activities of Three Selected Borwn Seaweeds of India. Food Chem., 107: 707-713.

Chen, Y., Cai, L., Zhao, C., Xu, H.C., Cao, C.Y. dan Liu, Y. 2008. Spectroscopic, Stability and RadicalScavenging Properties of a Novel Pigment from Gardenia. Food Chem., 109: 269-277.

Davis, A.R., Roberts, D.E. dan Cummins, S.P. 1997. Rapid Invasion of a Sponge-dominated Deep-reef by Caulerpa scalpelliformis (Chlorophyta) in Botany Bay, New South Wales Australia. J. Ecology., 22: 146-150.

Dixon, R.A. dan Paiva, N.L. 1995. Stress-induced Phenylpropanoid Metabolism. The Plant Cell., 7: 1085-1097.

Farag, R.S., Badei, A.Z.M., Hewadi, F.M. dan El-Baroty, G.S. 1989. Antioxidant Activity of Some Spice Essential Oils on Linoleic Acid Oxidation in Aqueous Media. J. Am. Oil Chem. Soc., 66: 792-799.

Food dan Nutrition Board. 2000. Proposed Definition and Plan for Review of Dietary Antioxidants and Related Compounds. National Academy Press, Washington, DC.

Harborne, J.B. 1984. Phytochemical Methods: A Guide to Modern Techniques of Plant Analysis Second Edition. Chapman and Hall Ltd, London.

Huckle, J.M., Potter, J.A. dan Marrs, R.H. 2000. Influence of Environmental Factors on the Growth and Interaction between Salt Marsh Plants: Effect of Salinity, Sediment and Water Logging. $J$. Ecology, 88: 492-505.

Je, J.Y., Park, P.J., Kim, E.K.B., Park, J.S., Yoon, H.D., Kim, K.R. dan Ahn, C.B. 2009. Antioxidant Activity of Enzymatic Extracts from the Brown Seaweed Undaria pinnatida by Electron Spin Resonance Spectroscopy. LWT- Food Sci. Tech., 42: 874-878.

Kadi, A. 1996. Pengenalan Jenis Algae Hijau (Chlorophyta). In: Atmadja, W.S., Kadi, A., Sulistijo, dan Rachmaniar (Eds). Pengenalan Jenis-Jenis Rumput Laut Indonesia. Puslitbang Osenologi, LIPI, Jakarta.

Kadi, A. 2000. Makroalga di Paparan Terumbu Karang Perairan Teluk Lampung. Puslitbang Osenologi, Lembaga Ilmu Pengetahuan Indonesia, Jakarta.

Kaur, C. dan Kapoor, H.C. 2001.Antioxidants in Fruits and Vegetables - The Millenium's Health (Review). Int. J. Food Sci. Tech., 36: 703-725.

Kumalaningsih, S. 2006. Antioksidan Alami Penangkal Radikal Bebas: Sumber, Manfaat, Cara Penyediaan dan Pengolahan. Trubus Agrisarana, Surabaya. 
Kumar, K.S., Ganesan, K. dan Rao, P.B.S. 2008. Antioxidant Potential of Solvent Extracts of Kappaphycus alvarezii (Doty) Doty - an Edible Seaweed. Food Chem., 107: 289-295.

Lee, C.D., Wang, S.B. dan Kuo, C.L. 1978. Benthic Macro Invetebrates and Fish as Indicator of Water Quality, with Reference to Community Diversity Index. Bull. C. Sci., 31: 233-238.

Lopez-Lopez, I., Bastida, S., Ruiz-Capilas, C., Bravo, L., Larrea, M.T., Sanchez-Muniz, F. dan Cofrades, S. 2009. Composition and Antioxidant Capacity of Low-salt Meat Emulsion Model System Containing Edible Seaweeds. Meat Sci., 83: 492-498.

Marin, A., Ferreres, F., Tomas-Barberan, F.A. dan Gil, M.I. 2004. Characterization and Quantitation of Antioxidant Constituents of Sweet Pepper (Capsicum annuum L.). J. Agric. Food Chem., 52: $3861-3869$.

Molyneux, P. 2004. The use of The Stable Free Radical Diphenylpicryl-hydrazil (DPPH) for Estimating Antioxidant Activity. Songklanakarin J. Sci. Technol., 26 (2): 211-219.

Moore, J., Liu, J.G., Zhou, K. dan Yu, L. 2006. Effects of Genotype and Environment on the Antioxidant Properties of Hard Winter Wheat Bran. J. Agric. Food Chem., 54: 5313-5322.

Moure, A., Cruz, J.M., Franco, D., Dominguez, M., Sineiro, J., Dominquez, H., Nunez, M.J. dan Parajo, J.C. 2001. Natural Antioxidants from Residual Sources (Review). Food Chem., 72: 145-171.

Muchtar, M. 2005. Penelitian Terpadu Ekologi dan Strain HAB (Harmfull Algal Blooming) di Perairan Teluk Hurun, Lampung. Laporan Penelitian. Pusat Penelitian Oseanografi, Lembaga Ilmu Pengetahuan Indonesia, Jakarta.

Nielseon, N.S. dan Jacobsen, C. 2009. Methods for Reducing Oxidation in Fish-oil-enrich Energy Bars. Int. J. Food Sci. Tech., 44: 1536-1546.

Papas, A.M. 1999. Diet and Antioxidant Status. Food Chem. Toxicol, 37: 999-1007.

Puja, Y., Sudjiharno dan Aditya, T.W. 2001. Teknologi Budidaya Rumput Laut Kappaphycus alvarezii. Balai Budidaya Laut Lampung, Lampung.

Reyes, L.F. dan Zevallos, L.C. 2003. Wounding Stress Increases the Phenolic Content and Antioxidant Capacity of Purple-flesh Potatoes (Solanum tuberosum L.). J. Agric. Food Chem., 51: 5296-5300.

Riechert, R. dan Dawes, C.J. 1986. Acclimation of the Green Alga Caulerpa racemosa var. uvifera to Light. Botanica Marina, 29: 533-537.

Rohman, A., Riyanto, S. dan Utari, D. 2006. Aktivitas Antioksidan, Kandungan Fenolik Total dan Kandungan Flavonoid Total Ekstrak Etil Asetat Buah Mengkudu Serta Fraksi-Fraksinya. Majalah Farmasi Indonesia, 17 (3): 136-142.
Santoso, J., Yoshie, Y. dan Suzuki, T. 2002. The Distribution and Profile of Nutrients and Catechins of Some Indonesian Seaweeds. Fish. Sci., 68 (suppl): 1647-1648.

Santoso, J., Yoshie-Stark, Y. dan Suzuki, T. 2004. Antioxidant Activity of Methanol Extract from Indonesian Seaweeds in an Oil Emulsion Model. Fish. Sci., 70: 183-188.

Santoso, J., Aryudhani, N. dan Suseno, S.H. 2009. Kandungan Senyawa Fenol Rumput Laut Hijau Caulerpa racemosa dan Aktivitas Antioksidannya. J. Kelautan Nasional, 2: 100-118.

Santoso, J., Maulida, R. dan Suseno, S.H. 2010. Aktivitas Antioksidan Ekstrak Metanol, Etil Asetat dan Heksana Rumput Laut Hijau Caulerpa lentillifera. J. Ilmu Kelautan, 1: 1-10.

Shahidi, F. dan Wanasundara, P.K.J.P.D. 1992. Phenolic Antioxidant. Crit. Rev. Food Sci. Nutr., 32: 67-103.

Sharma, O.P. dan Bhat, T.K. 2009. DPPH Antioxidant Assay Revisited. Food Chem., 113: 1202-1205.

Shiu, C.T. dan Lee, T.M. 2005. Ultraviolet-B-induced Oxidative Stress and Responses of the Ascorbate-glutathione Cycle in a Marine Macrolga Ulva fasciata. J. Exp. Botany., 56 (421): 2851-2865.

Steel, R.G.D. dan Torrie, J.H. 1980. Principles and Procedures of Statistic a Biometrical Approach. McGraw-Hill Book Company, London.

Wang, T., Jónsdóttir, R. dan Ólafsdóttir, G. 2009. Total Phenolic Compounds, Radical Scavenging and Metal Chelation of Extracts from Icelandic Seaweeds. Food Chem., 116: 240-248.

Winarno, F.G. 1997. Kimia Pangan dan Gizi. Gramedia Pustaka Utama, Jakarta.

Wresdiyati, T., Adnyane, I.K.M., Prabandari, S.A. dan Sofiawati. 2004. Profil Imunohistokimia Antioksidan Copper,Zinc-Superoxide Dismutase $(\mathrm{Cu}, \mathrm{Zn}-\mathrm{SOD})$ pada Ginjal Tikus Perinantal dan Neonantal. Biota, IX (3): 163-170.

Wresdiyati, T., Astawan, M., Adyane, I.K.M. dan Prasetyawati, R.C. 2005. Pemanfaatan Oleoresin Jahe (Zingiber officinale) untuk Mengatasi Kelainan Antioksidan Intrasel Superoxide Dismutase (SOD) Hati Tikus Di Bawah Kondisi Stress. Biota, X (2): 120-128.

Yoshie, Y., Wang, W., Petillo, D. dan Suzuki, T. 2000. Distribution of Catechins in Japanese Seaweeds. Fish. Sci., 66: 998-1000.

Yoshiki, M., Tsuge, K., Tsuruta, Y., Yoshimura, T., Koganemaru, K., Sumi, T., Matsui, T. dan Matsumoto, K. 2009. Production of New Antioxidant Compound from Mycosporine-Like Amino Acid, Porphyra-334 by Heat Treatment. Food Chem., 113: 1127-1132. 